DOI: https://doi.org/10.36477/tourismhospcee-1-1

УДК 640.4:338.48:339.138:005

Барна М. Ю.

доктор економічних наук, професор, перший проректор, професор кафедри туризму та готельно-ресторанної справи Львівського торговельно-економічного університету ORCID: https://orcid.org/0000-0001-5248-9774 Researcher ID: G-9493-2019

Гліненко Л. К. кандидат технічних наук, доцент, доцент кафедри електронних засобів інформаційно-комп'ютерних технологій Національного університету «Львівська політехніка» ORCID: https://orcid.org/0000-0002-3105-4568 Researcher ID: K-3740-2017

Дайновський Ю. А.

доктор економічних наук, професор, завідувач кафедри маркетингу Львівського торговельно-економічного університету ORCID: https://orcid.org/0000-0001-8421-2104 Researcher ID: F-3903-2019

\author{
Barna Marta \\ Lviv University of Trade and Economics \\ Hlinenko Larysa \\ National University "Lvivska Polytechnika" \\ Daynovskyy Yuriy \\ Lviv University of Trade and Economics
}

\title{
МАРКЕТИНГОВІ ДОСЛІДЖЕННЯ У СФЕРІ ГОТЕЛЬНО-РЕСТОРАННОГО І ТУРИСТИЧНОГО БІЗНЕСУ: ПРОБЛЕМИ І НЕДОЛІКИ
}

\author{
MARKETING RESEARCHES IN THE HOTEL-RESTAURANT \\ AND TOURISM INDUSTRY: PROBLEMS AND SHORTCOMINGS
}

Стаття присвячена питанням організації, змісту і логіки маркетингових досліджень у сфері готельно-ресторанного та туристичного бізнесу. Метою статті є систематизація помилок, изо мають місие у маркетингових дослідженнях для мінімізації у майбутньому їх кількості і негативного впливу на підприємницькі рішення. Проаналізовані типові помилки у маркетингових дослідженнях, серед яких: опитування разових, випадкових клієнтів як постійних; надмірна кількість груп, на які розбиваються респонденти; неврахування унікальності закладів і поліфакторності їх вибору споживачами; постановка більшої, ніж необхідно, кількості питань; переоцінка рівня кваліфікації респондентів у предметі дослідження; використання закритих запитань у ситуаціях, коли можсливими є багато варіантів відповідей респондентів; об'єднання декількох запитань в одному; відсутність націленості дослідження на конкретні управлінські рішення; постановка недосяжних иілей; недостовірність і нерепрезентативність інформації, на підставі якої можуть прийматися рішення у сфері туристичного і готельно-ресторанного бізнесу. На підставі аналізу низки сайтів обтрунтовано «годинник» конкурентоспроможного сайту, який повинен містити 12 блоків, щзо є обов 'язковими з точки зору впливу на потенційних замовників. Підкреслено, щзо подальщі дослідження дочільно було б спрямувати на регулярний моніторинг здійснюваних маркетингових досліджень і узагальнення типів можливих помилок з метою їх недопущення у майбутньому.

Ключові слова: маркетингові дослідження, готельно-ресторанний бізнес, туристичний бізнес, опитування, достовірність інформації, помилки.

Статья посвящена вопросам организации, содержания и логики маркетинговых исследований в сфере гостинично-ресторанного и туристического бизнеса. Целью статьи является систематизация ошибок, которые имеют место в маркетинговых исследованиях для минимизации в будущеем их количества и негативного воздействия на предпринимательские решения. Проанализированы типичные ошибки в маркетинговых исследованиях, среди которых: опрос разовых, случайных клиентов как постоянных; чрезмерное количество групп, на которые разбиваются респонденты; неучитывание уникальности заведений и поли- 
факторности их выбора потребителями; постановка большего, чем необходимо, количества вопросов; переоценка уровня квалификации респондентов в предмете исследования; использование закрытых вопросов и ситуачиях, когда возможны много вариантов ответов респондентов; объединение нескольких вопросов в одном; отсутствие нацеленности исследования на конкретные управленческие решения; постановка недостижниых изелей; недостоверность и нерепрезентативность информации, на основании которой могут приниматься решения в сфере туристического и гостинично-ресторанного бизнеса. На основании анализа ряда сайтов обоснованы «часы» конкурентоспособного сайта, которые должны содержать 12 блоков, являюшихся обязательными с точки зрения воздействия на потенциальных заказчиков. Подчеркнуто, что дальнейшие исследования иелесообразно было бы направить на регулярный мониторинг осуществляемых маркетинговых исследований и обобщение типов возможных ошибок с иелью их недопущения в будущем.

Ключевые слова: маркетинговые исследования, гостинично-ресторанный бизнес, туристический бизнес, опросы, достоверность информации, очибки.

The article considers the organisation, content and logic of marketing researches in the sphere of hotelrestaurant and tourist business and examines the shortcomings occurring in the process of such researches. The aim of the article is to systematise the mistakes that happen in marketing research for minimising their amount as well as their potential negative impact on entrepreneurial decisions in the future. It is shown that problems in marketing research can arise even when solving relatively simple tasks such as determining the number of institutions operating in the field under study. It is stated that there are certain discrepancies in the data given in various sources, and the reason for such discrepancies can be attributed, in particular, to mixing of different classification groups, vagueness of the criteria for referring a particular institution to a certain category, and arbitrariness of self-positioning of individual establishments. Typical mistakes in marketing research in the field of hotel-restaurant and tourist business are analysed. These mistakes include: interviewing one-time occasional customers as regular ones; treating uncritically the ranges of scales with variants of answers offered to respondents; excessive number of groups into which respondents are divided; failure to consider uniqueness of establishments and polyfactoriality of their choice by consumers; putting more questions than necessary; overestimating the level of respondents' skills in the research subject; failure to take into account the differences in importance of individual factors or criteria; the use of closed-ended questions in situations with multiple possible answers of respondents; combining several questions within one; lack of research focus on specific managerial decisions; setting unachievable goals; unreliability of information upon which decisions are to be based. The dependence of respondents' choice of certain proposed alternatives on the number of these alternatives and the question formulation has been analysed. The importance of compliance with the requirements of the International Code of Marketing and Social Research regarding the clear distinction between the results obtained and the researcher's interpretation of them has been emphasized. The relevance of the requirement to ensure and adequately assess the representativeness of research in the field of tourism and hotel-restaurant business is pointed out. A number of leading catering company websites have been analysed to justify a competitive catering company website "clock", which should contain 12 blocks mandatory to impact on potential customers. It is shown that such a "clock" can be recommended for the websites of all hotel, restaurant and travel companies. It is emphasized that further research would be advisable to focus on regular monitoring of ongoing market researches and summarizing the types of possible errors in order to avoid them in the future.

Keywords: marketing research, hotel and restaurant business, tourism business, surveys, reliability of information, mistakes.

JEL Classification: C81, L83, L84, M31

Постановка проблеми. Маркетингові дослідження давно вже стали невід'ємною складовою діяльності підприємств усіх галузей економіки, не $є$ виключенням і галузі туризму і готельно-ресторанного господарства. Власників бізнесу цікавлять питання ємності ринку відповідних послуг і iï територіального розподілу, особливостей і тенденцій розвитку попиту споживачів і чинників, що на нього впливають, конкурентоспроможності окремих гравців на ринку i факторів іiі підвищення, розподілу загального попиту за категоріями закладів і багато інших аспектів ринку зазначених послуг. Відповіді на ці і подібні питання покликані дати маркетингові дослідження, проте якість їх організації і отримувані результати не завжди відповідають очікуванням замовників. Більше того, невірні результати можуть дезорієнтувати їх і спровокувати прийняття помилкових бізнес-рішень. У зв'язку з цим завжди актуаль- ним $є$ завдання вивчення існуючих проблем для ï вирішення або зменшення, а також аналізу фактично здійснених помилок для їх недопущення у майбутньому.

Аналіз останніх досліджень і публікацій. Проблематиці маркетингових досліджень вибору найбільш обгрунтованих методичних підходів i конкретних методик, а також особливостям їх практичної реалізації присвячено велику кількість праць вітчизняних i закордонних вчених, вони висвітлені у наукових статтях $[4 ; 6 ; 7 ; 8 ; 9$; $11 ; 17 ; 18 ; 20 ; 21 ; 25]$, монографіях [14], дисертаціях [5], навчальній літературі [10; 19], більшість 3 цих авторів акцентували свою увагу на маркетингових дослідженнях саме у галузі готельно-ресторанного господарства і туристичного бізнесу.

За останні роки опубліковано немало праць, в яких розглядаються концептуальні питання проведення маркетингових досліджень [4; 5; 9; 10, 14], 
проблеми інформаційного забезпечення $[6 ; 11 ; 18$; 24], а також презентуються конкретні методики проведення досліджень конкурентоспроможності підприємств $[4 ; 7 ; 8 ; 9 ; 15 ; 17 ; 20 ; 21]$, опитувань експертів 3 проблематики діяльності зазначених галузей $[5 ; 7 ; 15 ; 21]$ і споживачів 3 метою виявлення особливостей їхнього попиту $[3 ; 5 ; 8 ; 11 ; 20 ; 25]$.

Постановка завдання. Метою статті є систематизація помилкових підходів, що трапляються у маркетингових дослідженнях у сфері готельноресторанного і туристичного бізнесу, для мінімізації у майбутньому їх кількості і негативного впливу на підприємницькі рішення.

Виклад основного матеріалу дослідження. Про те, 3 якими труднощами може стикнутися дослідник ринку, намагаючись всього-на-всього визначити кількість місць, в яких здійснюється реалізація на певному ринку, яскраво свідчить ситуація у ресторанному господарстві України, яке зараз представлене орієнтовно п'ятьма тисячами підприємств $[18$, с. 20]. По-перше, незвичним для сприйняття $є$ той факт, що все, що колись називалося підприємствами громадського харчування тепер потрапило у категорію ресторанного господарства, до якого тепер зараховуються не тільки вишукані ресторани, але і скромні буфети, їдальні, закусочні, тобто всі місця, призначені для організації харчування людей. По-друге, слід розуміти, що не тотожними є поняття підприємства і закладу, адже у складі підприємства може бути декілька закладів харчування. У середньому в Україні на одне підприємство припадає більше двох закладів харчування [18, с. 20]. По-третє, усі ці заклади складають лише $44 \%$ від усіх закладів харчування в країні, оскільки крім них $€$ ще заклади харчування у складі підприємств, які за основною діяльністю відносяться за КВЕД до інших видів економічної діяльності крім «діяльності із забезпечення стравами та напоями», тобто формально не належать до ресторанного господарства (ресторани при готелях, буфети і їдальні у навчальних закладах, кафе на підприємствах чи в установах).

Загальна кількість закладів у складі підприємств ресторанного господарства (за КВЕД) становить 11,2 тисяч, а кількість таких закладів у складі підприємств-юридичних осіб інших видів економічної діяльності перевищує 14 тисяч [18, с. 20]. По-четверте, крім підприємств ресторанного господарства бізнесом у сфері організації харчування займаються також і фізичні особи-підприємці. У статистичних щорічниках Державної служби статистики України, на жаль, не виділяється інформація за видом економічної діяльності «діяльність iз забезпечення стравами та напоями», проте $є$ дані стосовно «тимчасового розміщування й організації харчування», тобто готельної і ресторанної справи разом, з яких відомо, що з 61,8 тисяч суб'єктів господарювання у галузі тільки 7,6 тисяч $(12,3 \%)$ - це підприємства, а решта 54,2 тисяч (87,7\%) - фізичні особи-підприємці [23, с. 412, 421], які організують роботу закладів у готельно-ресторанній галузі. Немає підстав вважати, що саме таким є співвідношення підприємств і фізичних осіб-підприємців у сфері харчування, але абсолютно зрозуміло, що дані про підприємства ресторанного бізнесу - це лише невелика частина усієї галузі ресторанного господарства.

Ці причини створюють певну розбіжність даних, що наводяться у різних джерелах про галузь ресторанного господарства. Так, у $[18$, с. 22] наводяться дані про те, що у структурі підприємств ресторанного господарства частка ресторанів становить майже 20 відсотків, частка їдалень $-9-10 \%$, барів $-15-16 \%$, кафе - 55\%. За іншими даними [6, с. 71] у структурі підприємств кафе і ресторанів - 46\%, барів, пабів та нічних клубів - 14\% і 40\% закладів категорії Fast Food.

Причиною розбіжності даних може також бути змішування різних класифікаційних груп, нечіткість критеріїв приналежності конкретного закладу до певної категорії, довільність самопозиціонування окремих закладів. Наприклад, поділ закладів харчування на кафе, ресторани, бари i Fast Food є некоректним, адже Fast Food може одночасно бути і кафе, і рестораном низькоцінової категорії. Так само некоректним $\epsilon$ виділення категорії мережевих підприємств поряд 3 кафе $\mathrm{i}$ ресторанами.

Нерідко питання віднесення закладу до певної категорії залишається на розсуд власників закладу. Так, немає чітких критеріїв, що давали б підстави для визначення відмінностей між пивною залою, пивним баром, пивним рестораном. Категорія «закусочна» розповсюджується на вареничні, млинцеві, пиріжкові, чебуречні, шашличні, піцерії, які на вивісці нерідко мають назву «кафе». Не ясно, до кафе чи до барів зараховувати заклад, якщо він має назву «кафе-бар». Мережа «Містер Снек», яка називається мережею сендвіч-барів, за пропонованим асортиментом більше нагадує мережу закусочних.

Коли йдеться про дослідження мережевих підприємств, слід враховувати, що поряд з традиційними мережами $з$ однаковою концепцією, уніфікованими стандартами бізнес-процесів, ціновою, маркетинговою, кадровою політикою, однаковою сировинною базою, які поширюються «тиражуванням» певного взірця, який позитивно зарекомендував себе на ринку («Макдональдс», «Пузата хата», «Швидко», «Мак Смак», «Містер Снек», «Челентано», «Домашня кухня»), у сфері ресторанного господарства існують і мережі іншого гатунку, які об'єднують різнопланові заклади, що можуть належати різним власникам. Такі мережі утворюються переважно заради досягнення більшої популярності і проведення спільної марке- 
тингової кампанії («Карт-Бланш», «Парадиз», «Світова карта», до 2019 року - «Козирна карта»).

При дослідженні окремих аспектів діяльності підприємств ресторанного господарства потрібно звертати увагу на те, чи реально реалізуються ті функції чи ті переваги, які мали б очікуватися від роботи відповідних закладів. Так, при аналізі діяльності мережі закладів слід з'ясувати чи реально реалізовані ті переваги, що зазвичай очікуються від мережі (централізація виконання окремих функцій - реклами, постачання, вирішення питань у державних органах; ширша поінформованість споживачів про бренд, просування нового закладу за рахунок успішної діяльності інших). При дослідженні діяльності закладів швидкого харчування необхідно вияснити, чи реально вони забезпечують порівняно низькі ціни внаслідок обмеженого асортименту і самообслуговування клієнтів, близькість розташування, швидкість обслуговування, демократичність та невимушеність обстановки, прогнозованість асортименту і ціни. Досліджуючи дотримання закладом концепції, прийнятої при його заснуванні, необхідно перевірити відповідність усіх елементів діяльності закладу зазначеній концепції (наприклад, недоречною буде неонова вивіска, якщо ресторан оформляється в історичному стилі або різьблене дерево при домінуванні футуристичного оформлення). При дослідженні асортименту додаткових послуг слід враховувати об'єктивну еволюцію розвитку, так, якщо раніше забезпечення доступу до Інтернет (Wi-Fi) можна було вважати додатковою послугою і окремо відображати у рекламі, то тепер це у більшості випадків вже не є перевагою, бо очікується за замовчуванням. Оцінюючи розширення асортименту додаткових послуг слід мати на увазі, що це не завжди підвищує рентабельність закладу загалом, адже у більшій мірі залежить від його концепції.

Проаналізуємо типові помилки маркетингових досліджень у сфері готельно-ресторанного господарства і туристичного бізнесу.

Помилка 1. Опитування разових, випадкових клієнтів як постійних. Якщо постійним клієнтам допустимо ставити питання про враження від ресторанів різних стилів (модерн, хай-тек, класицизм, етнічний стиль та ін.), то разових клієнтів, якими є значна частина відвідувачів ресторанів, доцільно запитувати про їх враження про конкретний випадок отримання послуги, який щойно відбувся. У звичайних їдалень, закладів фаст-фуду є багато постійних відвідувачів, тому можна вивчати причини відвідування саме цього закладу, аналогічне опитування в ресторанах $€$ не зовсім коректним, адже при цьому випадкові клієнти примушуються до висловлення узагальнених суджень, для яких у них переважно бракує споживацького досвіду [8].
Аналогічно слід розрізняти підходи до разових і постійних клієнтів у готельному і туристичному бізнесі. Будь-які програми лояльності мають сенс тільки у випадках, коли клієнт є постійним. У зв'язку з цим в готельному обслуговуванні слід диференційовано підходити до різних сегментів гостей: при поїздках, пов'язаних з бізнесом або відпочинком гість може стати постійним, при поїздках туристичного характеру таке трапляється дуже рідко. Споживачі туристичних послуг, навпаки, можуть бути прихильними до туристичних компаній, послугами яких вони раніше користувались. Відповідно у готельному бізнесі важливо досліджувати причини перебування своїх гостей і пропонувати програми лояльності з врахуванням результатів таких досліджень, а у туристичному бізнесі - при першому ж зверненні зараховувати клієнта до бази постійних 3 подальшим надсиланням йому нових пропозицій і дослідженням рівня його задоволеності і причин можливих звернень до послуг інших туристичних компаній.

Помилка 2. Некритичне ставлення до діапазонів шкал 3 варіантами відповідей, які пропонуються респондентам. Людина 3 місячним доходом до 1500 грн вже багато років навіть теоретично не може відвідувати ресторани, так само, як не можуть вважати себе особами 3 високим доходом ті, хто заробляє більше 3500 грн, отже навіть 10-15 років тому встановлення таких інтервалів відповідей було позбавлене сенсу [8]. Крім того, з викладацького досвіду добре відомо, що якщо у питанні про вік респондента пропонуються інтервали по 5 років $(20-25,26-30$ і т. д.), а останнім інтервалом є «50 і більше років», то можна стверджувати, що автором такої анкети точно була молода людина студентського віку.

Так само не логічно виглядають запитання про туристичні уподобання або преференції щодо послуг п'ятизіркових готелів в анкетах 3 нижньою межею доходів респондента, наприклад, у 5000 грн.

Помилка 3. Надмірна кількість груп, на які розбиваються респонденти. Репрезентативність визначається за загальною кількістю респондентів, після чого висновки формулюються на основі інформації про їх групи і підгрупи, на які за замовчуванням нібито розповсюджуються розраховані характеристики репрезентативності (без врахування того, що окремі групи чи підгрупи можуть бути представленими одним-двома респондентами). Для отримання мінімально репрезентативних висновків необхідно щоби найменша 3 підгруп була представлена хоча б малою вибіркою - 20 респондентами, але за розбивки усієї сукупності респондентів за трьома ознаками на 84 підгрупи [8, с. 95] та ще й з врахуванням нерівномірності розподілу, таке дослідження явно виходить за межі реальних можливостей дослідників. 
Помилка 4. Неврахування унікальності закладів ресторанного господарства і поліфакторності їх вибору споживачами. Кожний немережевий ресторан за сукупністю ознак є унікальним об'єктом 3 практично нескінченною кількістю факторів що зумовлюють рішення споживача відвідати або не відвідати його. Тому намагання визначити уподобання узагальнених стилів ресторану (модерн, хай-тек, класицизм, етнічний стиль) тільки через фактори віку і доходу респондента $є$ утопічними у своїй основі [8, с. 94].

Так само унікальною $€$ кожна туристична подорож, тому недоречними є спроби виясняти напрями, куди полюбляе подорожувати респондент: світ занадто великий і переважна більшість туристів воліє відвідувати ті місця, в яких вони ще не були. Якщо ж подорожі в одне і те саме місце повторюються, то їх вже не слід кваліфікувати як туризм, адже вони швидше за все пов'язані з бізнесом, відпочинком, оздоровленням, що змінює як цільові установки респондентів, так і комплекс факторів, які впливають на їхні рішення.

Помилка 5. Відсутність націленості дослідження на конкретні управлінські рішення. Суто пізнавальна мета характерна для фундаментальних досліджень. Дослідження ж у сфері готельно-ресторанного і туристичного бізнесу $\epsilon$ прикладними і мають бути орієнтованими на обгрунтування чітко окреслених управлінських дій, які реалізуються або ні, якщо дослідження показує (або не показує) певний результат. Просте виявлення факту, що люди 3 такими-то характеристиками віддають перевагу (та ще й з певною імовірністю) таким-то підприємствам, а люди 3 іншими характеристиками - якимось іншим можливо і дає певну пізнавальну інформацію, але у практичному плані позбавлене сенсу.

В одній $з$ анкет вибіркового опитування туристів [1] передбачено майже сто питань про гостя, мету його перебування, 3 ким подорожує, яким видом транспорту прибув, пересувався в Україні i буде покидати Україну, як часто приїжджає до України, які види діяльності або відпочинку здійснював протягом перебування в Україні, низка питань щодо організації подорожі (коли почав планувати, за туристичною путівкою чи самостійно), вартість різних елементів подорожі та ін. Це опитування звернуло на себе увагу тим, що жодне 3 питань не дозволяло обгрунтувати жодного управлінського рішення стосовно готельного обслуговування туриста, усі питання були присвячені виключно деталізації його характеристик і подробиць перебування в Україні.

Помилка 6. Постановка недосяжних цілей. Перед дослідниками іноді намагаються поставити завдання, які практично неможливо вирішити силами не тільки персоналу окремого підприємства, але і більш потужних наукових колективів, наприклад, визначити цільовий сегмент для пересічного розташованого у великому місті закладу швидкого харчування [8] або виявити потреби, уподобання і очікування потенційних відвідувачів, їх рівень доходів, місця праці, режими роботи, місця здійснення закупівель і продукти, які вони частіше купують [26]. Такі широко сформульовані і неконкретні завдання створюють передумови для їх невиконання i неможливості практично скористатися їх результатами.

Нерідко дослідники рівня конкурентоспроможності підприємств намагаються поставити респондентам забагато питань, явно переходячи межі компетентності більшості 3 них в окремих аспектах досліджуваної проблематики і реального часу, який міг би бути присвячений відповідям. Викликає великі сумніви, наприклад, чи зможе звичайний респондент виставити оцінку кожній 3 п'яти найбільш популярних кав'ярень міста за 18 критеріями (тобто виставити $18 \times 5=90$ оцінок), в т.ч. такими складними і специфічними, як [5, c. 195-198]:

- реклама, сторінки в соціальних мережах (звичайний респондент навряд чи за цим слідкуватиме);

- цінова політика (якщо підприємство банкрутуватиме внаслідок занижених цін, то за рівень цін респондент виставлятиме найвищий бал);

- якість використовуваних кавових зерен (споживач може сказати про якість напою, але навряд чи про якість зерна);

- вигідність розташування (кожний респондент вправі дати різну оцінку залежно від особливостей власного пересування містом).

Далеко не кожний респондент зможе оцінити і такі характеристики, як рівень соціальної спрямованості діяльності, спеціальні пропозиції для постійних клієнтів, якість послуги «кава з собою», збалансованість молоковмісних напоїв, рівень латте-арт, використання альтернативних методів заварювання кави.

Також важко уявити собі туриста, гостя міста, який буде старанно відповідати на майже сто питань анкети [1], серед яких є відкриті і табличні питання і багато питань про величину різноманітних витрат, пов'язаних $з$ подорожжю, які звичайний респондент далеко не завжди пам'ятає.

На наш погляд, враховуючи обмеженість реальних можливостей проведення маркетингових досліджень силами конкретних готелів, туристичних підприємств, закладів ресторанного господарства, доцільно зосереджувати увагу на організації збирання і нагромаджування інформації, отримуваної з випадкових джерел, з коротких розмов 3 клієнтами, зустрічей з гостями, які завітали до закладу. Причому зернини цієї інформації потраплятимуть до різних працівників підприємств - турагентів, адміністраторів готелів, 
покоївок, офіціантів, прибиральниць, охоронців, і завдання керівника - заохотити працівників до переказування такої інформації йому особисто або працівникові, в обов'язки якого входитиме нагромадження і систематизація відповідних даних. Ще одним важливим способом отримування маркетингової інформації $є$ мотивування гостей до заповнення анкет-відгуків про їх враження від перебування у закладі.

Проаналізуємо методику оцінки конкурентоспроможності ресторанів, висловлену у [21]. Можна цілком погодитися з ідеєю цієї методики і підтвердити доцільність ії практичного застосування. Зміст методики полягає у послідовному виконанні низки етапів: 1) визначення переліку критеріїв конкурентоспроможності ресторанів; 2) якісній бальній оцінці роботи конкретного ресторану за кожним з обраних критеріїв (наприклад, 0 балів за недотримання критерію або найгіршому рівні виконання вимог, які даний критерій передбачає, 3 бали за найкращий рівень відповідності вимогам критерію і певні проміжні рівні відповідності, що оцінюються у 1 і 2 бали); 3) підрахунок загальної суми балів щодо конкретного ресторану; 4) отримання відносної нормованої оцінки діленням набраної конкретним рестораном суми балів на максимально можливу кількість балів.

Для оцінки конкурентоспроможності ресторанів японської кухні запропоновані такі критерії $[21$, c. 519]: наявність блюд національної кухні, їх приготування за японськими традиціями; стилізація оформлення ресторану (в японському стилі); дотримання традиційного японського застільного етикету (сервіровка, оформлення страв, обслуговування); режим роботи закладу (кількість годин на добу); середній чек; кількість посадкових місць; кількість ресторанів мережі в місті; можливість доставки суші додому; можливість безкоштовної доставки; час очікування замовлення в ресторані; час очікування доставки замовлення додому; кількість додаткових послуг; можливість різних варіантів розрахунку; наявність знижок, дисконтних програм, знижок на день народження клієнта, за взяте з собою замовлення; наявність додаткових акцій.

До цієї загалом обгрунтованої методики слід додати низку зауважень. По-перше, при зазначеному підході усі критерії виступають як рівнозначні за важливістю. Складно погодитись, що у ресторані японської кухні, наприклад, приготування блюд за японськими традиціями або стилізація оформлення ресторану за японською культурою повинні враховуватися як рівноважні зі, скажімо, наявністю додаткових акцій або знижок на день народження клієнта. У зв'язку з цим, на наш погляд, доцільно було б враховувати різні вагомості окремих критеріїв і бали, отримані за кожним критерієм, перемножувати на наперед визначені експертним методом коефіцієнти важливості критеріїв. Можливий і простіший спосіб, коли більш важливі критерії мали б більший діапазон шкали оцінювання, наприклад, для найважливішого критерію - від 0 до 10, а для мінімально важливого - від 0 до 2 чи до 1.

По-друге, не можемо погодитись 3 тим, що кількість місць в ресторані або кількість ресторанів певної мережі у місті можуть бути в числі критеріїв конкурентоспроможності [21, с. 519], адже окремі клієнти можуть полюбляти саме невеличкі затишні або унікальні у певному сенсі ресторани.

По-третє, недоцільно за критерієм наявності додаткових послуг враховувати виключно їх кількість, адже вони теж можуть мати різну важливість для клієнтів.

По-четверте, не для кожного ресторану зменшення середнього чеку або збільшення відсотка знижки свідчитиме про підвищення конкурентоспроможності, адже це може призводити до зменшення виручки, а також не завжди відповідатиме концепції і ціновій політиці закладу.

Значною проблемою маркетингових досліджень $є$ забезпечення достовірності інформації, на підставі якої потім будуть даватися певні оцінки чи прийматися певні рішення. Так, порівняння конкурентоспроможності готелів, наведене у табл. 1 [15], провокує низку питань стосовно зазначених у ній оцінок. По-перше, важко уявити склад і спосіб знаходження дослідником тих респондентів або навіть експертів, які настільки ознайомлені зі станом справ у всіх п'яти досліджуваних готелях, що могли б дати такі оцінки. По-друге, не зрозуміло, про які саме спеціальні заходи або додаткові послуги йдеться, кожний респондент оцінюватиме тільки ті, з якими він ознайомлений, отже, різні респонденти оцінюватимуть різний склад заходів та послуг і, відповідно, виникає питання щодо співставності таких оцінок. По-третє, жоден респондент не може оцінити усієї реклами будь-якого готелю без спеціального дослідження цього питання. По-четверте, будьяке усереднення оцінок респондентів не може давати дискретних цілочисельних оцінок. Отже такий логічний аналіз наведеної таблиці дозволяє висловити обгрунтовані сумніви у достовірності наведених у ній даних.

Дослідження, проведене «Київською асоціацією шеф-кухарів» [22] серед ресторанів, що в рівних частках представляють елітні, середньоцінові і низькоцінові заклади показало, що ресторани цих груп по-різному ставляться до окремих антикризових заходів щодо приваблення клієнтів (табл. 2). Для аналізу даних цієї таблиці пропонуємо застосувати Індекс орієнтованості антикризового заходу на ціновий рівень ресторану $\left(\mathrm{I}_{\text {ощ }}\right)$. Якщо зважити показані у табл. 2 відсотки за графою елітних ресторанів, наприклад, на 1, за 
Таблиця 1

Оцінка конкурентоспроможності готелю «СВА»

\begin{tabular}{|l|c|c|c|c|c|}
\hline \multicolumn{1}{|c|}{ Показники } & $\begin{array}{c}\text { Готель } \\
\text { «Сва» }\end{array}$ & $\begin{array}{c}\text { Готель } \\
\text { «Легіон» }\end{array}$ & $\begin{array}{c}\text { Готель } \\
\text { «Домінік» }\end{array}$ & $\begin{array}{c}\text { Готель } \\
\text { «країна» }\end{array}$ & $\begin{array}{c}\text { Готель } \\
\text { «Атлас» }\end{array}$ \\
\hline Обслуговування & 5 & 5 & 4 & 4 & 5 \\
\hline Організація спеціальних заходів & 4 & 4 & 5 & 2 & 5 \\
\hline Комфортність номерів & 5 & 4 & 3 & 4 & 5 \\
\hline Додаткові послуги & 3 & 3 & 4 & 3 & 5 \\
\hline Реклама готелю & 5 & 3 & 3 & 2 & 4 \\
\hline Разом & 22 & 19 & 19 & 15 & 24 \\
\hline
\end{tabular}

Джерело: [15]

графою ресторанів 3 середніми цінами на 0,5 , а відсотками щодо ресторанів із низькими цінами знехтувати (зважити на 0), то можна отримати цей середньозважений індекс, діапазон значень якого від 0 (захід підтримується тільки низькоціновими закладами) до 100 (захід підтримується тільки елітними ресторанами). Як видно 3 табл. 2, серед антикризових заходів (тобто заходів щодо підвищення конкурентоспроможності у період кризи) ресторани високого і низького цінового сегменту у першу чергу акцентують увагу на тих сторонах своєї діяльності, які так або інакше пов'язані 3 кінцевими фінансовими показниками діяльності підприємств. Якщо елітні ресторатори серед першочергових заходів розглядають перегляд штатів на предмет можливого скорочення персоналу ( $80 \%$ усіх прихильників такого заходу, $\left.\mathrm{I}_{\text {оц }}=87,5\right)$ i ще більше підвищення цін $\left(65 \%, \mathrm{I}_{\text {оц }}=75\right)$, то зі зниженням цінового рівня закладів більше уваги приділяється скороченню витрат на рекламу $\left(\mathrm{I}_{\text {оц }}=52,5\right)$, збільшенню знижок $\left(\mathrm{I}_{\text {оц }}=45\right)$ у розрахунку на відповідне збільшення контингенту клієнтів і зменшенню привілеїв (сервісу) для кліснтів $\left(\mathrm{I}_{\text {оц }}=27,5\right)$ для зменшення витрат.

Один з методів вимірювання лояльності передбачає постановку респондентам питання «Яка ймовірність того, що Ви порекомендуєте під- приємство (послугу, бренд) друзям (знайомим, колегам)?» [3]. Оцінку пропонується здійснити за 10-бальною шкалою, де 0 означає, що респондент ні в якому разі не буде рекомендувати, а 10 - що обов'язково порекомендує. При такому дослідженні треба мати на увазі, що респондентами мають бути саме відвідувачі закладу, адже в одному 3 досліджень майже $50 \%$ опитаних визнали, що рекомендували послуги ресторанів, в яких самі ніколи не були, причому $28 \%$ відзначили, що роблять так не вперше [3, с. 41]. Крім того, за цієї методики дослідження цілком достатньо 5-бальної, максимум 7-бальної шкали, адже при більшій кількості позицій значну роль починає відігравати вже не реальне враження клієнта, а психологічне сприйняття ним діапазону цифрового ряду.

За результатами одного з опитувань працівників ресторанів встановлено, що основним засобом конкурентної боротьби підприємств ресторанного господарства $52 \%$ опитаних вважали ціну, 30\%якість і асортимент продукції і 15\% - рекламу [17]. Звертаємо увагу на те, що разом 97\% опитаних саме ці аспекти конкурентної боротьби ніби то вважали головними і тільки 3\% віддали перевагу іншим засобам. Враховуючи, що серед цих інших засобів, як мінімум мають бути присутніми якість

\section{Розподіл відповідей щодо ставлення ресторанів різних цінових груп до окремих антикризових заходів 3 приваблення кліснтів, \%}

\begin{tabular}{|l|c|c|c|c|}
\hline Заходи з приваблення кліснтів & $\begin{array}{c}\text { Елітні } \\
\text { ресторани }\end{array}$ & $\begin{array}{c}\text { Ресторани } \\
\text { із середніми } \\
\text { цінами }\end{array}$ & $\begin{array}{c}\text { Показник } \\
\text { Ресторани } \\
\text { із низькими } \\
\text { цінами }\end{array}$ & $\begin{array}{c}\text { оріснтованості } \\
\text { антикризового } \\
\text { заходу на ціновий } \\
\text { рівень ресторану }\end{array}$ \\
\hline Підвищення цін & 65 & 20 & 15 & 75 \\
\hline Скорочення персоналу & 80 & 15 & 5 & 87,5 \\
\hline Зменшення порцій & 40 & 40 & 20 & 60 \\
\hline Перегляд постачальників & 40 & 40 & 20 & 60 \\
\hline Зменшення привілеїв для клієнтів & 15 & 25 & 60 & 27,5 \\
\hline Оновлення меню & 40 & 40 & 20 & 50 \\
\hline Скорочення витрат на рекламу & 35 & 35 & 30 & 52,5 \\
\hline Збільшення знижок & 15 & 60 & 25 & 45 \\
\hline
\end{tabular}

Джерело: розраховано на основі [22] 
обслуговування, особливості місця розміщення, унікальність екстер'єру і інтер'єру закладу, стає абсолютно очевидним нереальність ситуації, коли разом цим факторам віддають перевагу лише $3 \%$ рестораторів, при тому, що $15 \%$ віддали перевагу рекламі. Причина такого співвідношення відповідей очевидно криється у некоректності проведеного дослідження, зокрема у обмеженості запропонованих альтернатив на окремі запитання анкети.

Так, наприклад, якщо на питання про головний засіб конкурентної боротьби були запропоновані альтернативи: ціна, якість і асортимент продукції, реклама, інший засіб (вкажіть, який), то відповіді респондентів дійсно могли бути такими, як зазначено вище, адже респонденту легше просто відзначити запропонований варіант, ніж самостійно формулювати власний. Крім того, небажання респондентів відповідати на відкриті альтернативи збільшується у міру підвищення розміру і складності анкети.

Якщо ж респондентам був би запропонований більший перелік альтернатив (ціна, якість блюд, асортимент, якість обслуговування, місце розміщення, особливості екстер'єру і інтер'єру, розважальна програма і музикальний супровід, дотримання санітарно-гігієнічних норм), то і результати опитування були б іншими. Результати опитування концентруються навколо запропонованих альтернатив i, таким чином, залежать не тільки від реальних думок респондентів, але і від конструкції окремих питань.

Крім того важливим $є$ і те, як саме звучало питання анкети: респондентів просили обрати один найважливіший на їх думку засіб, чи прорангувати запропоновані засоби за важливістю, чи просто відзначити кілька найважливіших. В останньому випадку не перше місце могла вийти не та альтернатива, яку більшість вважали головною, а просто та, яка була відмічена більшістю опитаних.

У достатньо репрезентативному дослідженні споживачів туристичних i готельних послуг [9, с. 40] стверджується, що $46 \%$ гостей, які проживали у готелі серед додаткових послуг обрали послугу харчування. Цей результат виглядає дещо дивним, адже відомо, що більшість гостей користуються принаймні сніданком. Подальше вивчення результатів дослідження показало, що серед додаткових послуг $11 \%$ гостей обрали розважальні програми, 8\% - послуги конференц-залу, 7\% - екскурсійну програму, 5\% - спортивно-оздоровчі послуги, 4\% - транспортні, $10 \%$ обрали послуги, яких не було у запропонованому дослідниками переліку і 9\% взагалі не користувалися додатковими послугами. Оскільки сума зазначених відсотків дорівнює $100 \%$, стає зрозумілим, що дослідники подають результати опитування так, ніби гість мав право вказати тільки один вид додаткових послуг, що є відвертою помилкою саме процедури обробки і представлення даних. Очевидно, що гості мали можливість обирати кілька додаткових послуг, і за $100 \%$ слід було приймати не загальну кількість відповідей, а кількість анкет, яка значно менша. Внаслідок такої помилки усі відсотки користувачів окремих послуг виявилися заниженими, а отже послугами харчування користувалися не $46 \%$ гостей, а більше, проте не можна встановити наскільки більше, оскільки дослідники не презентують повних даних дослідження.

Інакше кажучи, для того щоби вірно розуміти результати дослідження необхідно знати докладно і як було поставлено запитання, і в який спосіб було запропоновано давати відповіді. Не випадково однією з вимог Міжнародного кодексу маркетингових і соціальних досліджень є повний опис проведеного дослідження і чітка відокремленість отриманих результатів від їх інтерпретації дослідником [16, стаття 26].

Нерідко недоліком анкет буває використання закритих запитань у ситуаціях, коли варіантів відповіді респондента може бути багато і необхідними $є$ напівзакриті питання. Наприклад, для запитання «Що саме, на Ваш погляд, потрібно вдосконалювати у нашому готелі?» явно недостатньо закритого віяла відповідей: а) якість харчування; б) асортимент послуг; в) якість обслуговування; г) цінову політику. У даному випадку бракуватиме альтернатив, пов'язаних 3 комфортністю номеру, можливостями паркування, режимом роботи та іншими аспектами обслуговування. Крім того, кожну з зазначених альтернатив доцільно було $б$ деталізувати, адже, наприклад, проста констатація недостатнього асортименту послуг не дає відповіді на питання, яких саме послуг гостю не вистачало. Тобто такого типу питання, по-перше, повинні мати значно більший асортимент варіантів пропонованих респонденту відповідей, а, по-друге, обов'язково містити можливість дописування іншої відповіді, не передбаченої серед наявних альтернатив.

Досить розповсюдженим $є$ бажання отримати комплексну оцінку певної ситуації або процесу i внаслідок цього фактичне об'єднання декількох запитань в одному. Так, готель «Шепільська» у анкеті для гостей [2] пропонує низку питань 3 проханням оцінити за шестибальною системою (від 0 до 5):

- Як Ви оцінюєте процеси прийому та інформування на рецепції: оперативність, компетентність і доброзичливість адміністратора?

- Як Ви можете оцінити зручність та комплектацію номеру?

- Чи задоволені Ви роботою покоївок, якістю та частотою прибирання?

- Ваша оцінка прилеглої території: чистота, затишок, комфорт? 
- Як Ви можете оцінити чистоту та атмосферу залу ресторану?

- Ваша оцінка щодо асортименту та якості страв?

- Наскільки доброзичливим і кваліфікованим $€$ обслуговування офіціантів?

- Ваша оцінка роботи персоналу СПА-центру (компетентність та комунікабельність адміністратора)?

- Як Ви б оцінили якість надання додаткових послуг у СПА-центрі (наприклад, масаж, обгортання, процедури у косметолога)?

Незрозуміло, як повинен відповідати респондент, якщо адміністратор або офіціант був доброзичливим, але некомпетентним, некваліфікованим. Покоївки можуть прибирати номер часто, але неякісно, якість страв може бути відмінною, але асортимент занадто вузьким, клієнт може бути у захваті від роботи масажиста, але обурений обслуговуванням у косметолога. У всіх подібних випадках респондент переважно усереднюватиме свою оцінку i, відповідно, дослідник не зможе іiі адекватно інтерпретувати.

Одне 3 проведених нами досліджень полягало в аналізі низки сайтів провідних кейтерингових компаній 3 метою виявлення кращих рекламних прийомів впливу на потенційних споживачів. У процесі дослідження ми дійшли висновку, що усі добре організовані і інформаційно наповнені сайти об'єднує низка характерних рис (блоків). Проведений аналіз дає підстави запропонувати «Годинник» конкурентоспроможного сайту кейтерингової компанії, який повинен містити 12 блоків, що є обов'язковими 3 точки зору впливу на потенційних замовників. Аналогічний «годинник» може бути рекомендований для сайтів усіх готельно-ресторанних і туристичних підприємств.

1. Лаконічний рекламний слоган («Ми зробимо Ваше свято безтурботним!», «Меню будь-якої кухні світу на ваш вибір», «Корпоративне харчування під ключ») або більш розлогий рекламний заклик до потенційного замовника («Нехай цей день буде найказковішим у житті! Не обмежуй себе банальними ресторанами. Ліс, гори, сад, берег річки - ми зробимо весілля у значимому та комфортному для тебе та твоїх близьких місці»).

2. Перелік видів пропонованих послуг (фуршети, перерви на каву, корпоративні вечірки, банкети, весілля, барбекю та ін.).

3. Вказування можливих діапазонів щодо окремих параметрів обслуговування: кількість гостей (наприклад, від 10 до 500 осіб), місця проведення (наприклад, на відстані до 150 км від Львова).

4. Фото- і відеоматеріали, які дозволяють наочно побачити, як виглядають блюда, сервіровані столи, декорації, процес обслуговування.

5. Інформація про загальну кількість виконаних замовлень, постійних клієнтів, задоволених гос- тей, які були обслужені. Перелік найбільш відомих постійних клієнтів 3 їх логотипами (останнє важливо, адже потенційний клієнт може швидше вирізнити відомий йому логотип, ніж прочитати назву підприємства).

6. Інформація про досвід роботи фірми на ринку кейтерингу.

7. Інформація про професіоналізм працівників (наприклад, кухарі української, італійської, японської кухонь, офіціанти міжнародного класу, досвід роботи усіх працівників не менше двох років).

8. Фотографії, відеоматеріали, які знайомлять потенційних клієнтів 3 найкращими працівниками фірми, і одночасно дають можливість помітити майстерність офіціантів професіоналізм кухарів, чистоту на кухні, чіткість взаємодії працівників.

9. Отримані відгуки задоволених клієнтів про якість блюд, процес обслуговування, їх загальне враження, а також інформація про обговорення послуг фірми у соціальних мережах.

10. Інформація про те, що ціни не є високими порівняно 3 ресторанним обслуговуванням i іншими кейтеринговими компаніями, або вони $€$ на 10-20 відсотків нижчими від середньоринкових, що досягається на підставі здійснення постійного моніторингу ринку кейтерингу, завдяки правильному плануванню ресурсів, продуманому меню, досвіду роботи.

11. Інформація про те, що замовник попередньо отримує оцінку вартості кейтерингу на конкретному замовленому заході.

12. Блок оформлення Інтернет-замовлення (контактні дані замовника, тип події, кількість персон, бюджет на одну персону, місце проведення та ін.)

Чітке інформаційне наповнення сайту фактами, унаочненнями, відеоматеріалами щодо кожного з зазначених блоків, зручне їх розташування, а також відсутність перевантаження окремих 3 цих блоків або зайвих даних, що не підпадають під жоден з зазначених блоків є вагомою передумовою успішної комунікації i, як наслідок, ефективності сайту, про що свідчитимуть, у першу чергу, замовлення від нових клієнтів.

У процесі аналізу саме на контрасті зі змістовністю і гарним оформленням більшості сайтів особливо звернули на себе увагу (за принципом ложки дьогтю у бочці меду) поодинокі негативні фрагменти, викликані, швидше за все, неуважністю окремих виконавців. Так, у відеофільмі працівниця приминає котлети, що смажаться, тією ж самою рукавичкою, якою торкалася за поверхню плитки і ручки посуду [12], анонсуються п’ять причин, чому варто обирати саме цю фірму, а далі називаються тільки чотири [12], для підкреслення цінової доступності послуг компанії підкреслюється, що «правильне планування ресурсів, про- 
думане меню та досвід роботи дозволяють нам конкурувати із, навіть, недешевими ресторанами у частині цін та якості» замість «недорогими», що очевидно передбачалося за контекстом [13].

Як вже було зазначено, однією 3 важливих передумов проведення ефективних маркетингових досліджень є обгрунтована класифікація явищ або процесів, які досліджуються. Крім існуючих класифікацій кейтерингового обслуговування [19] за контингентами споживачів (фірми, установи, підприємства, посольства, спілки, комітети, асоціації, колективи, приватні особи), за об'єктами обслуговування (ділові зустрічі, презентації, конференції, семінари, корпоративні вечірки, семінари, збори, благодійні бенкети, випускні бали, дні народження, ювілеї, весілля, комплексні обіди, сніданки, вечері), за місцем проведення (у приміщенні, на лоні природи, у транспорті, при проведенні масових заходів), а також за видами обслуговування (фуршет, шведський стіл, кавабрейк, коктейль, пікник, барбекю, банкет і т.п.) доцільно також виділити класифікації:

1) за призначенням:

а) заходи для забезпечення безперервності трудового процесу (кава-брейк, організація обідів);

б) заходи для згуртування колективу (корпоративна вечірка);

в) заходи для відзначення певних подій (ювілей, весілля);

г) суто розважальні заходи (пікнік);

д) комплексні заходи (кава-брейк + вечеря під час проведення конференціі);

2) за складом замовників:

а) на замовлення підприємств (корпоративні заходи, семінари);

б) на групове замовлення (випускні вечори);

в) на індивідуальні замовлення (дні народження, ювілеї, весілля);

3) за частотою проведення:

а) постійні (обіди);

б) періодичні (корпоративи);

в) разові (весілля);

4) за місцем приготування їжі і характером обслуговування:

а) доставка готових закусок та страв в коробках;

б) доставка з обслуговуванням;

в) обслуговування 3 приготуванням блюд у місці замовлення.

Відповідно, при здійсненні маркетингових досліджень кейтерингового обслуговування можна рекомендувати дотримуватися саме такої системи класифікації, що дозволить отримувати коректні результати i вірно їх інтерпретувати в процесі прийняття управлінських рішень.

Однією $з$ найважливіших складових маркетингових досліджень у сфері туристичного i готельно-ресторанного бізнесу $є$ забезпечення i адекватна оцінка їх репрезентативності. Про- блему репрезентативності досліджень гостей, які проживають у готелях можна проілюструвати на прикладі опитувань в'їзних туристів проведених під час розробки стратегії підвищення конкурентоспроможності міста Львова [24]. Протягом 1,5 років було проведено три опитування і логічно припустити, що за умови достатньої репрезентативності кожного з них їх результати мали б бути достатньо подібними.

У табл. 3 показані максимальні і мінімальні (3 трьох проведених опитувань) значення характеристик окремих досліджуваних параметрів. На наш погляд, якщо би кожне дослідження було репрезентативним, то таких значних розбіжностей у відсотках респондентів, що обирали певні варіанти відповідей, не повинно було б бути. Ще більші розбіжності між зазначеними трьома дослідженнями показала оцінка респондентами окремих місць у м. Львові як ключових його атракцій (табл. 4).

На наш погляд, цілком обгрунтованим є метод апостеріорної оцінки репрезентативності вибірки шляхом іiї випадкового поділу на групи 3 подальшою перевіркою міри співпадіння досліджуваних ознак у групах. У зазначеному джерелі [24] групи утворилися внаслідок проведення трьох окремих досліджень за однаковою програмою. Якщо показники груп $є$ подібними, це $є$ непрямим свідченням репрезентативності груп і усієї сукупності досліджуваних одиниць, яка кількісно суттєво більша, відповідно, ступінь принаймні кількісної репрезентативності додатково підвищується. Якщо дані груп не $\epsilon$ подібними, відповідно, це свідчить про недостатню репрезентативність досліджень. Якісну репрезентативність досліджуваних вибірок респондентів доцільно оцінювати з використанням відповідей про самих респондентів: їх структура за віком, рівнем доходів, статтю, місцем проживання та іншими ознаками повинна бути співставною 3 аналогічною структурою усього населення або досліджуваного його сегмента. Такий підхід до оцінки репрезентативності доцільно використовувати у маркетингових дослідженнях у сфері туристичного і готельно-ресторанного бізнесу.

Висновки і перспективи подальших досліджень. 3 викладеного матеріалу видно, що у сфері маркетингових досліджень існує досить широкий арсенал методичних підходів, проте кожний 3 них містить певні «підводні камені», існування яких треба передбачати ще на етапі проектування дослідження, для того, щоби його результати могли об'єктивно відобразити дійсність і дати підстави для прийняття обгрунтованих управлінських рішень. Подальші наукові опрацювання доцільно було б спрямовувати на регулярний моніторинг здійснюваних маркетингових досліджень i узагальнення типів можливих неточностей і помилок 3 метою їх ширшого наукового обговорення i, відповідно, недопущення у майбутніх дослідженнях. 
Значення окремих досліджуваних параметрів, отримані під час опитувань гостей міста Львова

Таблиця 3

\begin{tabular}{|c|c|c|c|}
\hline \multirow[b]{2}{*}{ Параметри } & \multicolumn{2}{|c|}{ Відсоток відповідей } & \multirow[b]{2}{*}{$\begin{array}{l}\text { Розбіжність, } \\
\text { разів }\end{array}$} \\
\hline & $\begin{array}{c}\text { мінімальний серед } \\
\text { трьох опитувань } \\
\end{array}$ & $\begin{array}{c}\text { максимальний серед } \\
\text { трьох опитувань }\end{array}$ & \\
\hline Частота відвідування м. Львова - дуже часто & 9 & 44 & 4,9 \\
\hline $\begin{array}{l}\text { Преференції щодо житла для зупинок на ніч } \\
\text { - готель }\end{array}$ & 29 & 43 & 1,5 \\
\hline $\begin{array}{l}\text { Тривалість перебування у м. Львові: } \\
\text { - без ночівлі } \\
\text { - більше } 7 \text { ночей }\end{array}$ & $\begin{array}{l}6 \\
7\end{array}$ & $\begin{array}{l}22 \\
17\end{array}$ & $\begin{array}{l}3,7 \\
2,4\end{array}$ \\
\hline $\begin{array}{l}\text { Ключові джерела інформації для планування } \\
\text { подорожі - туристичний агент }\end{array}$ & 5 & 11 & 2,2 \\
\hline $\begin{array}{l}\text { Причина приїзду до м. Львова: } \\
\text { - відвідування філії компанії } \\
\text { - відвідування виставки-ярмарки }\end{array}$ & $\begin{array}{l}8 \\
6\end{array}$ & $\begin{array}{l}17 \\
26\end{array}$ & $\begin{array}{l}2,1 \\
4,3\end{array}$ \\
\hline $\begin{array}{l}\text { Мета подорожі - відірватись від рутини } \\
\text { щоденного життя }\end{array}$ & 10 & 21 & 2,1 \\
\hline $\begin{array}{l}\text { Причини вибору саме м. Львова, а не інших } \\
\text { напрямів для поїздки: } \\
\text { - престижне місце } \\
\text { - зручне транспортне сполучення } \\
\text { - недалеко }\end{array}$ & $\begin{array}{l}5 \\
8 \\
6\end{array}$ & $\begin{array}{l}18 \\
23 \\
14\end{array}$ & $\begin{array}{l}3,6 \\
2,9 \\
2,3\end{array}$ \\
\hline $\begin{array}{l}\text { Ключові види проведення часу у Львові: } \\
\text { - ресторани } \\
\text { - екскурсія за місто з гідом } \\
\text { - походи в магазини }\end{array}$ & $\begin{array}{c}12 \\
6 \\
12\end{array}$ & $\begin{array}{l}23 \\
14 \\
21\end{array}$ & $\begin{array}{l}1,9 \\
2,3 \\
1,8\end{array}$ \\
\hline
\end{tabular}

Джерело: розраховано на основі [24]

Таблиця 4

Оцінка окремих об'єктів як ключових атракцій міста Львова

\begin{tabular}{|l|c|c|c|}
\hline \multirow{2}{*}{\multicolumn{1}{|c|}{ Об'єкти }} & \multicolumn{2}{|c|}{$\begin{array}{c}\text { Відсоток опитаних, які назвали об'єкт } \\
\text { у переліку ключових атракцій міста }\end{array}$} & \multirow{2}{*}{ Розбіжність, разів } \\
\cline { 2 - 3 } & $\begin{array}{c}\text { мінімальний } \\
\text { серед трьох опитувань }\end{array}$ & $\begin{array}{c}\text { максимальний } \\
\text { серед трьох опитувань }\end{array}$ & \\
\hline Ратуша & 28 & 68 & 2,4 \\
\hline Театр опери та балету & 31 & 73 & 2,4 \\
\hline Ринок «Вернісаж» & 15 & 50 & 3,3 \\
\hline Домініканський собор & 11 & 42 & 3,8 \\
\hline Вірменська церква & 7 & 45 & 6,4 \\
\hline Аптека-музей & 4 & 37 & 9,3 \\
\hline Музей Арсенал & 10 & 48 & 4,8 \\
\hline Церква святого Юри & 11 & 40 & 3,6 \\
\hline
\end{tabular}

Джерело: розраховано на основі [24]

\section{Список використаних джерел:}

1. Анкета вибіркового опитування відвідувачів (туристів та одноденних відвідувачів). URL: https://www.dst.dk/ Site/Dst/SingleFiles/GetArchiveFile.aspx?fi=842027219\&fo=0\&ext=ukraine (дата звернення: 02.03.2021).

2. Анкета гостя готеля - Шепільська. URL: http://shepilska.com.ua/anketa/ (дата звернення: 02.03.2021).

3.Баран О. П. Управління конкурентоспроможністю закладу ресторанного господарства. Тернопіль : ТНЕУ, 2017. $100 \mathrm{c}$.

4. Басюк Д. І., Мельник Д. О. Комплексний підхід до оцінки якості послуг готельних підприємств. Економіка та держава. 2019. № 3. С. 30-33.

5. Воронюк Т. А. Формування механізму управління конкурентоспроможністю підприємств ресторанного господарства : дис. ... канд. екон. наук : 08.00.04 / Одеська національна академія харчових технологій. Одеса, 2019. $200 \mathrm{c}$.

6. Гірняк Л. І., Глагола В. А. Сучасний стан, перспективи та тенденції розвитку ресторанного господарства в Україні. Інфраструктура ринку. 2018. № 16. С. 71-78. 
7. Дружиніна В. В. Використання експертного методу для оцінки конкурентоспроможності ресторанних закладів у туристичній сфері. Економіка і суспільство. 2019. Вип. 20. С. 221-228.

8. Дружиніна В. В., Зінченко Д. С., Кириченко А. В. Імідж як вагомий фактор конкурентноспроможності закладів ресторанного господарства. Вісник Донецьького національного університету. Серія В: Економіка і право. 2015. Вип. 1. С. 92-95.

9.Кізима В. Л., Бортнік Н. В. Маркетингове дослідження ринку туристичних і готельних послуг України. Науковий вісник Херсонського держсавного університету. Серія Економічні науки. 2016. Вип. 17. Ч. 2. С. $37-40$.

10.Ковешников В. С., Матвієнко А. Т., Разметова О. Г. Організація готельно-ресторанного господарства : навч. посіб. Київ : Ліра-К, 2018. 564 с.

11.Кожушко С. П., Захарова С. Г. Маркетингові дослідження та методи збору маркетингової інформації в сучасному готельному підприємстві. Держава та регіони. 2020. № 4(115). С. 81-84.

12.Компанія ArtCatering. URL: http://artcatering.lviv.ua (дата звернення: 02.03.2021).

13.Компанія Chef. URL: www.chef.lviv.ua (дата звернення: 02.03.2021).

14.Конкурентоспроможність підприємства: оцінка рівня та напрями підвищення : монографія / за заг. ред. О. Г. Янкового. Одеса : Атлант, 2013. 470 с.

15.Маркетингове дослідження готелю "СBA". URL: https://knowledge.allbest.ru/marketing/3c0b65635b2ad78b5c 43a89521206d37_0.html (дата звернення: 02.03.2021).

16.Міжнародний процесуальний кодекс маркетингових i соціальних досліджень ICC/ESOMAR. URL: https://refdb.ru/look/1609285.html (дата звернення: 02.03.2021).

17.Нагернюк Д. В. Основні чинники, що формують конкурентоспроможність підприємств ресторанного господарства. Ефективна економіка. 2016. № 9. URL: http://www.economy.nayka.com.ua/?op=1\&z=5142 (дата $3 в е р-$ нення: 02.03.2021).

18.Обозна А. О., Шабельник Н. М., Федотов І. А. Аналіз сучасного ринку ресторанних послуг та ефективність їх застосування на підприємстві. Інвестиції: практика та досвід. 2019. № 13. С. 17-23.

19.Організація кейтерингового обслуговування. URL: https://pidruchniki.com/13500826/turizm/organizatsiya_ keyteringovogo_obslugovuvannya (дата звернення: 02.03.2021).

20.Погасій С. О., Краснокутська Ю. В., Нікітіна І. В. Аналіз основних трендів розвитку ринку готельних послуг. Проблеми і перспективи розвитку підприємництва. 2019. № 23. С.180-191.

21.Приходько Д. О. Теоретичні аспекти конкурентоспроможності ресторанів японської кухні. Глобальні та національні проблеми економіки. 2016. Вип. 14. С. 516-521. URL: http://global-national.in.ua/issue-14-2016/22vipusk-14-gruden-2016-r/2599-prikhodko-d-o-teoretichni-aspekti-konkurentospromozhnosti-restoraniv-yaponskojikukhni (дата звернення: 02.03.2021).

22. Ринок ресторанного бізнесу України (2010). URL: http://poglyad.com/blog-4/post-437 (дата звернення: 02.03.2021).

23.Статистичний щорічник України за 2018 рік. Державна служба статистики України. Житомир : ТОВ «Букдрук», 2019. 482 с.

24.Стратегія підвищення конкурентоспроможності міста Львова. Огляд опитування в’їзних туристів. URL: https://www.city-adm.lviv.ua/lmrdownloads/turystu/2010_11_18_Inbound_Tourism_Survey_Repor_UKR.pdf (дата звернення: 02.03.2021).

25.Чепурда Г. М., Івашина Л. Л. Проблеми розвитку готельного господарства у місті Черкаси під час пандемії. Інновації та технології в сфері послуг і харчування. 2020. № 2. С. 5-12.

26.8 шагов к успешному планированию продвижения ресторана. URL: http://prohotelia.com/2014/12/successfulrestaurant-promotion-plan/ (дата звернення: 02.03.2021).

\section{References:}

1. Anketa vybirkovoho opytuvannia vidviduvachiv (turystiv ta odnodennykh vidviduvachiv), (2005), "Questionnaire for a sample survey of visitors (tourists and one-day visitors)", available at: https://www.dst.dk/Site/Dst/SingleFiles/ GetArchiveFile.aspx?fi=842027219\&fo=0\&ext=ukraine (accessed 2 March 2021).

2. Anketa hostia hotelia - Shepil's'ka, (2019), "Hotel guest questionnaire - Shepilska", available at: http://shepilska.com.ua/ anketa/ (accessed 2 March 2021).

3. Baran, O. P. (2017), Upravlinnia konkurentospromozhnistiu zakladu restorannoho hospodarstva, [Managing the competitiveness of a restaurant enterprise], TNEU, Ternopil', Ukraine.

4. Basiuk, D. I. and Mel'nyk, D. O. (2019), Kompleksnyj pidkhid do otsinky iakosti posluh hotel'nykh pidpryiemstv, Ekonomika ta derzhava, "A comprehensive approach to assessing the quality of hotel enterprise services", Economics and State, vol. 3, pp. 30-33.

5. Voroniuk, T. A. (2019), Formuvannia mekhanizmu upravlinnia konkurentospromozhnistiu pidpryiemstv restorannoho hospodarstva, "Formation of a competitiveness management mechanism for restaurant enterprises", dissertation Ph.D, Economic sciences, Odesa National Academy of Food Technologies, Odesa, Ukraine.

6. Hirniak, L. I., and Hlahola, V. A. (2018), Suchasnyj stan, perspektyvy ta tendentsii rozvytku restorannoho hospodarstva v Ukraini, Infrastruktura rynku, "Current state, prospects and trends of the restaurant industry in Ukraine", Market Infrastructure, vol. 16, pp. 71-78.

7. Druzhynina, V. V. (2019), Vykorystannia ekspertnoho metodu dlia otsinky konkurentospromozhnosti restorannykh zakladiv u turystychnij sferi, Ekonomika i suspil'stvo, "Application of the expert method for evaluating the competitiveness of restaurant establishments in the tourism sector", Economy and Society, vol. 20, pp. 221-228. 
8. Druzhynina, V. V., Zinchenko, D. S., and Kyrychenko, A. V. (2015), Imidzh iak vahomyj faktor konkurentnospromozhnosti zakladiv restorannoho hospodarstva, Visnyk Donets'koho natsional'noho universytetu, Seriia B: Ekonomika $i$ pravo, "Image as a significant competitiveness factor in the restaurant industry", Bulletin of Donetsk National University. Series B: Economics and Law, vol. 1, pp. 92-95.

9. Kizyma, V. L. and Bortnik, N. V. (2016), Marketynhove doslidzhennia rynku turystychnykh i hotel'nykh posluh Ukrainy, Naukovyj visnyk Khersons'koho derzhavnoho universytetu, Seriia Ekonomichni nauky, "Marketing survey of the Ukrainian market of tourist and hotel services", Scientific Bulletin of Kherson State University, Series Economic Sciences, vol. 17 , no. 2 , pp. $37-40$.

10.Koveshnykov, V. S., Matviienko, A. T. and Razmetova, O. H. (2018), Orhanizatsiia hotel'no-restorannoho hospodarstva [Hotel and restaurant business organisation], textbook, Lira-K, Kyiv, Ukraine.

11. Kozhushko, S. P. and Zakharova, S. H. (2020), Marketynhovi doslidzhennia ta metody zboru marketynhovoi informatsii v suchasnomu hotel'nomu pidpryiemstvi, Derzhava ta rehiony, "Marketing research and methods of collecting marketing information in a modern hotel enterprise", State and Regions, vol. 4(115), pp. 81-84.

12. Kompaniia ArtCatering (2020), “ArtCatering Company”, available at: http://artcatering.lviv.ua (accessed 2 March 2021).

13.Kompaniia Chef (2020), "Chef Company", available at: www.chef.lviv.ua (accessed 2 March 2021).

14. Konkurentospromozhnist' pidpryiemstva: otsinka rivnia ta napriamy pidvyschennia (2013), [Enterprise competitiveness: assessment of the level and directions of increase], monohrafiia, za zah. red. Yankovoho O. H., Atlant, Odesa, Ukraine.

15. Marketynhove doslidzhennia hoteliu "YeVA" (2015), “"EBA" hotel marketing research", available at: https://knowledge.allbest.ru/marketing/3c0b65635b2ad78b5c43a89521206d37_0.html (accessed 2 March 2021).

16. Mizhnarodnyj protsesual'nyj kodeks marketynhovykh i sotsial'nykh doslidzhen' ICC/ESOMAR (2015), "International Code of Practice for Market and Social Research ICC/ESOMAR", available at: https://refdb.ru/look/1609285.html (accessed 2 March 2021).

17. Naherniuk, D. V. (2016), Osnovni chynnyky, scho formuiut' konkurentospromozhnist' pidpryiemstv restorannoho hospodarstva, Efektyvna ekonomika, "The main factors contributing to the competitiveness of the restaurant industry", Effective Economics, vol. 9, available at: http://www.economy.nayka.com.ua/?op=1\&z=5142 (accessed 2 March 2021).

18. Obozna, A. O., Shabel'nyk, N. M. and Fedotov, I. A. (2019), Analiz suchasnoho rynku restorannykh posluh ta efektyvnist' ikh zastosuvannia na pidpryiemstvi, Investytsii: praktyka ta dosvid, "Analysis of the current restaurant services market and the effectiveness of applying these services at the enterprise", Investments: Practice and Experience, vol. 13, pp. 17-23.

19.Orhanizatsiia kejterynhovoho obsluhovuvannia (2019), "Organising a catering service", available at: https://pidruchniki.com/13500826/turizm/organizatsiya_keyteringovogo_obslugovuvannya (accessed 2 March 2021).

20.Pohasij, S. O., Krasnokuts'ka, Yu. V. and Nikitina, I. V. (2019), Analiz osnovnykh trendiv rozvytku rynku hotel'nykh posluh, Problemy i perspektyvy rozvytku pidpryiemnytstva, "Analysis of the main development trends in the market of hotel services", Problems and Prospects of Entrepreneurship Development, vol. 23, pp.180-191.

21.Prykhod'ko, D. O. (2016), Teoretychni aspekty konkurentospromozhnosti restoraniv iapons'koi kukhni. Hlobal'ni ta natsional'ni problemy ekonomiky, "Theoretical aspects of the Japanese cuisine restaurants' competitiveness", Global and National Economic Problems, vol. 14, pp. 516-521, available at: http://global-national.in.ua/issue-14-2016/22vipusk-14-gruden-2016-r/2599-prikhodko-d-o-teoretichni-aspekti-konkurentospromozhnosti-restoraniv-yaponskojikukhni (accessed 2 March 2021).

22. Rynok restorannoho biznesu Ukrainy (2010), "Restaurant business market in Ukraine”, available at: http://poglyad.com/ blog-4/post-437 (accessed 2 March 2021).

23. Statystychnyj schorichnyk Ukrainy za 2018 rik, Derzhavna sluzhba statystyky Ukrainy (2019), [Statistical Yearbook of Ukraine 2018, State Statistics Service of Ukraine], TOV «Buk-druk», Zhytomyr, Ukraine.

24. Stratehiia pidvyschennia konkurentospromozhnosti mista L'vova. Ohliad opytuvannia v'iznykh turystiv (2010), "A strategy for enhancing the competitiveness of the city of Lviv. Review of the inbound tourist survey", available at: https://www.city-adm.lviv.ua/lmrdownloads/turystu/2010_11_18_Inbound_Tourism_Survey_Repor_UKR.pdf (accessed 2 March 2021).

25.Chepurda, H. M. and, Ivashyna, L. L. (2020), Problemy rozvytku hotel'noho hospodarstva u misti Cherkasy pid chas pandemii, Innovatsii ta tekhnolohii v sferi posluh $i$ kharchuvannia, "Problems of the development of the hotel industry in the city of Cherkasy during the pandemic", Innovation and Technology in Services and Nutrition, vol. 2, pp. 5-12.

26.8 shagov k uspeshnomu planirovaniju prodvizhenija restorana (2014), "8 steps to successful planning of restaurant promotion", available at: http://prohotelia.com/2014/12/successful-restaurant-promotion-plan/ (accessed 2 March 2021). 